\title{
Correlation between Global Longitudinal Strain and Ischemic Burden from Myocardial Perfusion Imaging SPECT in Multivessel Stable Coronary Artery Disease Patients
}

\author{
Rian Apriza*, Harris Hasan*, Ali Nafiah Nasution
}

Department of Cardiology and Vascular Medicine, Faculty of Medicine, Universitas Sumatera Utara-Haji Adam Malik General Hospital, Medan, North Sumatera, Indonesia

\section{ARTICLE INFO \\ *Corresponding author \\ email: \\ hasan1956@yahoo.com, \\ rianapriza@gmail.com \\ address: \\ Jalan pasar 2, \\ Komplek TPI blok A no. 52, \\ Medan 20132}

Keywords:

GLS; ischemic burden; SPECT

Manuscript submitted: September 10, 2019

Revised and accepted: January 31, 2020

\begin{abstract}
Backgroud: Global Longitudinal Strain (GLS) is a direct echocardiographic assessment of myocardial fiber deformation performed by speckle-tracking echocardiography that can better reflect ischemic and infarct areas and left ventricular function. Ischemic burden is a measurement of ischemic myocardium percentage and can be used to determine the management strategy of Multivessel Coronary Artery Disease (MVCAD). We aimed to investigate the value of GLS to predict the ischemic burden as detected by SPECT Myocardial Perfusion Imaging (MPI).
\end{abstract}

Method: A cross-sectional study of patients with Multivessel Coronary Artery Disease who underwent Cardiac SPECT were included. GLS is assessed using the Automated Function Imaging (AFI) technique that is performed on the same day as the SPECT examination. Ischemic burden was measured by SPECT MPI using semi-quantitative scores on 17-segment assessment according to standard nomenclature and interpreted as small and moderatelarge ischemic burden.

Result: Total of 52 patients ( 40 males, mean age $56 \pm 6.5$ years). There was negative correlation with good strength between GLS value and ischemic burden $(r=-0.706, P<0.001)$. Using ROC analysis, the optimal cut off value of GLS was $<(-13 \%)$ that yielded the highest sensitivity and specificity to discriminate between small and moderate-large ischemic burden. Sensitivity, specificity, positive and negative predictive value of GLS $\leq(-13 \%)$ to predict moderate-large ischemic burden as detected by SPECT analysis were $80 \%$, $75 \%, 67 \%$, and $86 \%$, respectively.

Conclusion: A GLS value is a reliable parameter with good diagnostic value to predict small ischemic burden $(<10 \%)$ as detected by SPECT MPI. This parameter could also be applied to determine the management strategy of Multivessel Coronary Artery Disease (MVCAD) patients in daily practice.

\section{INTISARI}

Latar Belakang: Global Longitudinal Strain (GLS) adalah penilaian ekokardiografi langsung dari deformasi serat miokardium yang dilakukan dengan speckle-tracking echocardiography yang dapat merefleksikan area iskemik dan infark dan fungsi ventrikel kiri secara lebih baik. Ischemic burden merupakan suatu faktor prognostik pada pasien dengan penyakit jantung koroner dan menjadi pedoman tatalaksana revaskularisasi pada pasien Penyakit Jantung Koroner (PJK) yang melibatkan beberapa pembuluh darah (multivessel coronary artery disease). Penelitian ini bertujuan untuk mengetahui nilai GLS dalam menilai besarnya ischemic burden melalui 
pemeriksaan Sidik Perfusi Miokard (SPM) menggunakan Single Photon Emission Computed Tomography (SPECT).

Metode: Penelitian ini adalah studi potong lintang pada pasien yang terdiagnosa multivessel coronary artery disease yang menjalani pemeriksaan SPECT jantung. GLS dinilai menggunakan teknik Automated Function Imaging (AFI) yang dilakukan pada hari yang sama saat pemeriksaan SPECT. Ischemic burden diukur menggunakan pemeriksaan sidik perfusi miokard dengan skor semikuantitatif pada penilaian 17 segmen sesuai standar dan diinterpretasikan menjadi ischemic burden kecil dan sedang-besar

Hasil: Total 52 pasien (40 laki-laki, rerata usia $56 \pm 6,5$ tahun). Dijumpai adanya hubungan berbanding terbalik yang bermakna antara nilai GLS dan ischemic burden dengan kekuatan korelasi yang kuat $(r=-0,706, P<0,001)$. Dengan menggunakan kurva ROC, didapatkan titik potong nilai GLS $\leq-13 \%$ yang memiliki sensitivitas dan spesifisitas tertinggi untuk membedakan antara ischemic burden kecil dan sedang-besar. Sensitivitas, spesifisitas, positive dan negative predictive value potong nilai GLS $\leq-13 \%$ untuk menilai adanya ischemic burden sedang-besar adalah $80 \%, 75 \%, 67 \%$, dan $86 \%$.

Kesimpulan: Nilai GLS merupakan suatu parameter yang memiliki nilai diagnostik yang baik untuk memprediksi adanya ischemic burden kecil $(<10 \%)$ dalam pemeriksaan sidik perfusi miokard menggunakan SPECT. Parameter ini juga dapat digunakan untuk menentukan strategi tatalaksana pasien-pasien multivessel coronary artery disease dalam praktek klinis sehari-hari.

\section{Introduction}

Cardiovascular disease is one of the main causes of increased mortality and morbidity in both developed and developing countries. One of the highest cardiovascular diseases causes death is coronary artery disease (CAD). One of the most severe subset of CAD is Multivessel Coronary Artery Disease (MVCAD), which is defined as the presence of stenosis lesions $\geq 50 \%$ of the coronary artery diameter as evidenced by coronary angiography in at least 2 of 3 major epicardial coronary arteries or its large branches. $^{1}$

In clinical practice, the ischemic burden is a parameter that is most often measured in examining myocardial perfusion imaging (MPI). Ischemic burden is a prognostic factor in patients with coronary heart disease., ${ }^{2,3}$ Along with the management guidelines, this parameter can identify patients who may benefit from revascularization compared to drug therapy. ${ }^{4}$ The existence of an ischemic burden of total $10 \%$ of the total myocardium becomes a threshold where revascularization will benefit patients compared to drug therapy alone. ${ }^{5,6}$ The main noninvasive nuclear imaging modality for performing myocardial perfusion is to use Single-Photon Emission-Computed Tomography (SPECT). This SPECT examination is able to (i) determine the location of ischemic regions to determine the appropriate plan for revascularization and (ii) assess the extent and severity of the heart part. ${ }^{7}$

Global Longitudinal Strain (GLS) is a direct echocardiographic assessment of myocardial fiber deformation performed by speckle-tracking echocardiography. The orientation of the longitudinal myocardial fiber is located in the sub-endocardium which is an area that is susceptible to ischemia. This makes the examination of longitudinal strains sensitive to ischemia. ${ }^{8}$

In a study that assessed the relationship of GLS in STEMI patients to assess Infarct size (IS) from the results of examination of Myocardial Perfusion using SPECT, a strong correlation was found between the GLS systolic peak value and the Infarct size of the Myocardial Perfusion Imaging. ${ }^{9}$ This result is in line with a study that states that the GLS value is strongly influenced by the presence of residual ischemia in the myocardium in STEMI patients who are subject to MPI examination to measure Infarct size. $^{10}$

The aim of this study was to examine GLS values from echocardiography to predict the ischemic burden value assessed by fingerprint examination of myocardial perfusion using SPECT in patients with Multivessel Coronary Artery Disease.

\section{Methods}

This study is a cross-sectional study at Haji Adam Malik Hospital Medan (RSHAM) with permission from the Research Ethics Committee of the Faculty of Medicine, University of North Sumatra-RSHAM. Subjects taken from February 2019 to May 2019. This study evaluate GLS from echocardiography as a diagnostic parameter that can be used to assess the ischemic burden assessed by examination of myocardial perfusion using SPECT in patients with Multivessel Coronary Artery Disease (MVCAD) based on coronary angiography which performed within 1 month. The inclusion criteria were patients who were documented as patients with Multivessel Coronary Artery Disease (presence of stenosis lesions $>50 \%$ diameter of coronary arteries as evidenced 
by coronary angiography in at least 2 of the 3 major epicardial coronary arteries or large branches). While exclusion criteria are poor echo window results or GLS examination cannot be performed, patients cannot complete optimal cardiac SPECT examination, patients with left main disease, and patients with Atrial Fibrillation.

\section{Study Procedure}

Before a cardiac SPECT examination is carried out, an echocardiographic examination is performed on patients who are included in the inclusion criteria on the same day. Echocardiography is performed with the lateral decubitus position using a Vivid GE S6 machine with a $3.50 \mathrm{Mhz}$ sector heart probe. GLS examination using the speckle tracking software on 17 segments of three standard apical views (3-chamber, 4-chamber, and 2-chamber). Endocardium boundaries are then automatically traced by software. The graph display of the deformity parameter then appears automatically. GLS values were obtained from the mean peak values of systolic strains from 17 longitudinal strains. Echocardiography is performed by 2 cardiologist non-invasive diagnostic division. subjects then performed cardiac SPECT examinations using radiographs of Tc-99m Sestamibi protocol 1 day with pharmacological burden in the form of Dobutamine. Dobutamine dose is given by intravenous infusion which starts from a dose of $5-10 \mathrm{mcg} / \mathrm{kg} /$ minute which is gradually increased in intervals of 3 minutes to a maximum dose of $40 \mathrm{mcg} / \mathrm{kg} /$ minute.

Radiopharmaceutical is injected at the peak heart rate (85\% of the predicted maximum heart rate) and Dobutamine infusion continues until after 1 minute radiopharmaceutical injection. The examination will be stopped in patients who experience complaints such as chest pain, vertigo, cold sweat, palpitations or shortness of breath, haemodynamic deterioration or malignant EKG changes during the examination, then the patient will be excluded from the study. SPECT examination using ECGgated rotating $90^{\circ}$ fixed dual-head gamma camera (Philips Medical System, Cleveland). SPECT results are processed using the AutoQuant software developed by Cedars-Sinai Medical Center (Los Angeles, California). The $<10 \%$ ischemic burden is categorized as a small ischemic burden, while the ischemic burden of $\geq 10 \%$ is categorized as a moderate-large ischemic burden. The heart SPECT results will be interpreted by a Nuclear Medicine Specialist and Cardiologist.This study is blind because the researchers did not participate in the examination of echocardiography and SPECT scan.

\section{Statistical analysis}

Categorical variables are presented by number or frequency (n) and percentage (\%). Numerical variables are represented by mean and standard deviation. For statistical analysis, a Spearman correlation test was conducted between GLS values and the results of the ischemic burden to find correlations and strengths of correlation between these two variables. If the results show a significant correlation then the cut-off value of the GLS value will be examine using an analysis of the
Receiver Operating Characteristic curve, then the diagnostic value of the GLS value will be carried out according to the cut-off value obtained to assess the magnitude of the ischemic burden according to the SPECT results of the heart. Bivariate analysis to test GLS values with myocardial perfusion parameters via SPECT will be tested by Chi-square and Fisher's Exact and to obtain negative predictive value (NPV) and positive predictive value (PPV). To see the differences in characteristics expressed with numerical variables, the Independent $\mathrm{T}$ test is used for data that are normally distributed, whereas if not normally distributed, the Mann Whitney test is used. Analysis of statistical data using statistical software, the value of $\mathrm{p}<0.05$ was said to be statistically significant.

\section{Result \\ Baseline Characteristics}

The total subjects of this study was 52 people who had met the inclusion and exclusion criteria. Male were 40 people $(76.9 \%)$ with the average age of subjects was $56 \pm 6.5$ years. Global longitudinal strain had a mean of $12.5 \pm 3.3 \%$.

Table 1.

Baseline Characteristics

\begin{tabular}{l|l}
\hline Parameters & $\mathrm{n}=52$ \\
\hline Age (mean \pm SD), years Gender, $\mathrm{n}(\%)$ & $56 \pm 6.5$ \\
$\quad$ Male & $40(76.9)$ \\
$\quad$ Female & $12(23.1)$ \\
Risk Factors, n (\%) & $26(50)$ \\
& \\
Diabetes Mellitus type II, n (\%) & $23(44.2)$ \\
Hypertension, n (\%) & $22(44.3)$ \\
Dyslipidemia, $\mathrm{n}(\%)$ & $31(59.6)$ \\
Smoking, $\mathrm{n}(\%)$ & $23.2 \pm 2.8$ \\
Body mass index (mean \pm SD) & $71 \pm 13$ \\
$\begin{array}{l}\text { Glomerular filtration rate } \\
\text { (mL/min/1.73m2) (mean } \pm S D)\end{array}$ & $37.1 \pm 2.4$ \\
$\begin{array}{l}\text { Ejection fraction by Echo (\%), (mean } \pm S D \\
\text { Global longitudinal strain (\%), } \\
\text { (mean } \pm \text { SD) }\end{array}$ & $-12.5 \pm 3.3$ \\
\hline
\end{tabular}

\section{Correlation between GLS Value and Ischemic Burden}

Spearman correlation test was conducted to assess the relationship between GLS values and the ischemic burden obtained from the results of cardiac SPECT examination analysis. GLS has been found to have strong negative correlation with ischemic burden values (Spearman rho $0.706, \mathrm{P}<0.001$ ). The negative correlation found in these subjects illustrates that the more negative the GLS value on the examination of echocardiography, the greater ischemic burden will be obtained on cardiac SPECT examination (figure 1). 


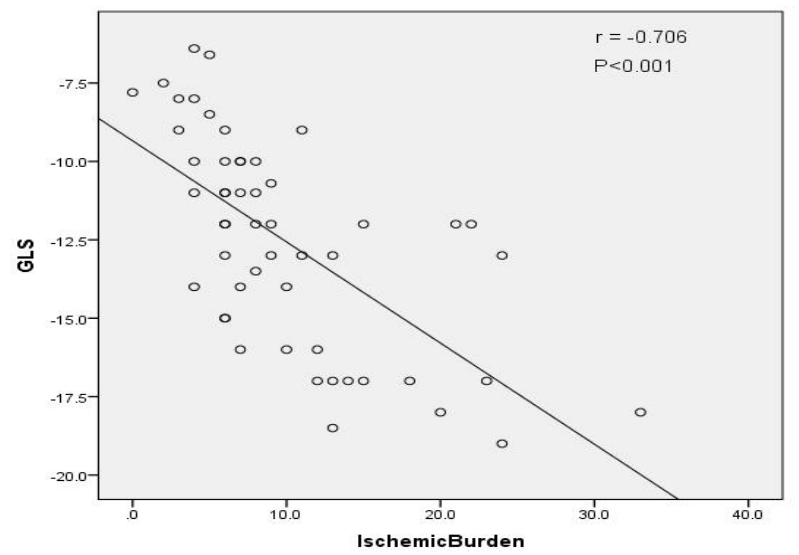

Figure 1. Scatter plot showing strong negative correlation of GLS and ischemic burden

The cut-off value of the GLS value in assessing the ischemic burden

Using the Receiver Operating Characteristic (ROC) and Area Under Curve (AUC) analysis, the GLS value cutoff value $(-13 \%)$ is considered have a significant discrimination power in determining the ischemic burden based on cardiac SPECT results. Determination of the GLS cutoff value $\leq(-13 \%)$ to determine a moderate-large ischemic burden $(>10 \%)$ and GLS value $>(-13 \%)$ to determine a small ischemic burden $(<10 \%)$ is taken into account that this intersection has the good sensitivity $(80 \%)$ and specificity $(75 \%)$ where AUC was 0.875 (P $<0.001$ ) (figure 2).

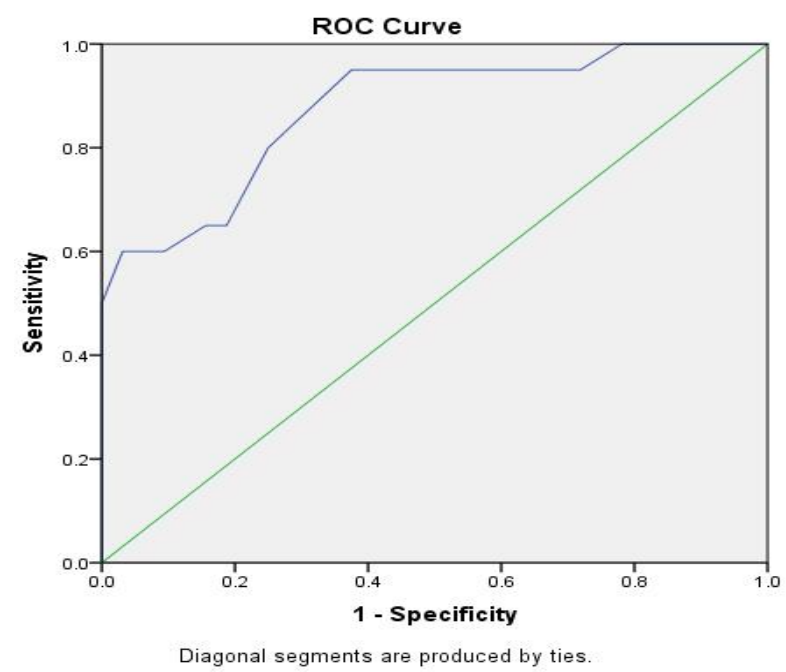

Figure 2. The ROC Curve of GLS to differentiate small to moderate-large ischemic burden

Diagnostic test results of GLS values for the ischemic burden

Table 2 shows the comparison of the results of GLS values with the two ischemic burden groups. In the group with GLS values $\leq(-13 \%) 16$ subjects $(80 \%)$ were proven to have moderate-large ischemic burden, while only 8 subjects $(25 \%)$ were proven to have small ischemic burden $(\mathrm{P}<0.001)$. Whereas with GLS values > $(-13 \%), 24$ subjects $(75 \%)$ were proven to have small ischemic burden, while only 4 subjects (20\%) with moderate-large ischemic burden $(\mathrm{P}<0.001)$.

In the results of the diagnostic test, the GLS value $\leq(-13 \%)$ had $80 \%$ sensitivity, $75 \%$ specificity, $67 \%$ Positive Predictive Value (PPV) and 86\% Negative Predictive Value (NPV) to determine a moderate-large ischemic burden on Myocardial Perfusion Imaging uses SPECT (Table 3).

Table 2.

Comparison of ischemic burden groups based on GLS values

\begin{tabular}{llll}
\hline \multirow{2}{*}{ Variable } & \multicolumn{2}{l}{ Ischemic burden } & p value \\
\cline { 2 - 3 } & $\begin{array}{l}\text { Moderate-large } \\
(\mathrm{n}=20)\end{array}$ & $\begin{array}{l}\text { Small } \\
(\mathrm{n}=32)\end{array}$ & \\
\hline GLS value & & $8(25)$ & $<0.001$ \\
$\leq-13, \mathrm{n}(\%)$ & $16(80)$ & $24(75)$ & \\
$>-13, \mathrm{n}(\%)$ & $4(20)$ & & \\
\hline
\end{tabular}

Table 3.

Diagnostic test of GLS for Ischemic Burden

\begin{tabular}{llllll}
\hline $\begin{array}{l}\text { GLS } \\
(\%)\end{array}$ & $\begin{array}{l}\text { Sensitivity } \\
(\%)\end{array}$ & $\begin{array}{l}\text { Specificity } \\
(\%)\end{array}$ & $\begin{array}{l}\text { Negative } \\
\text { Predictive } \\
\text { Value (\%) }\end{array}$ & $\begin{array}{l}\text { Positive } \\
\text { Predictive } \\
\text { Value (\%) }\end{array}$ & p value \\
\hline$\leq(-13)$ & 80 & 75 & 86 & 67 & $<0.001$ \\
\hline
\end{tabular}

Intra and Inter-observer variability on Ischemic Burden values and GLS values

SPECT Scan results are interpreted by a Nuclear Medicine Specialist and Cardiologist. The Cohen's Kappa Coefficient ( $\kappa)$ value for inter-observer variability is 0.795 which is included in the excellent category with a value of $p<0.001$ (Table 4). Measurement of GLS values was examined by 2 cardiologists from the Department of Cardiology and Vascular Medicine at Adam Malik General Hospital. The Cohen's Kappa Coefficient $(\kappa)$ value for intra-observer variability is 0.885 , while the Cohen's Kappa Coefficient $(\kappa)$ value for inter-observer variability is 0.807 which falls into the excellent category with a $\mathrm{p}<0.001$ (Table 5).

Table 4.

Inter-observer Variability Test (Cohen's Kappa Coefficient) Ischemic Burden

\begin{tabular}{|c|c|}
\hline Variable & Kappa (к p value \\
\hline Ischemic Burden (Inter-observer) & $<0.001$ \\
\hline
\end{tabular}

Table 5.

Intra and Inter-observer Variability Test (Cohen's Kappa Coefficient) GLS

\begin{tabular}{lll}
\hline Variable & Kappa $(\kappa)$ & p value \\
\hline GLS Value (Intra-observer) & 0.885 & $<0.001$ \\
GLS value (Inter-observer) & 0.807 & $<0.001$ \\
\hline
\end{tabular}

\section{Discussion}

Previous study compared GLS values between two groups with significant CAD severity (> 70\%) and non-significant ones $(<70 \%)$ in the CAD population. The mean GLS values in the group with significant stenosis $(>70 \%)$ was -11.86 $\pm 2.89 \% .{ }^{11}$ This is not different from the results of this 
study where the mean GLS values ranged from -12.5+ $3.3 \%$ in the same population of CAD patients with stenosis severity (> 70\%) to more than 1 coronary artery.

The results of the analysis of the correlation of GLS values with the ischemic burden through the Spearman test resulted in a strongnegative correlation $(\mathrm{r}=-0.706, \mathrm{P}$ $<0.001$ ). Similar to previous studies which found that GLS values had a fairly strong correlation $(r=0.79)$ with a viability index. ${ }^{12}$ Another study also obtained a strong correlation $(\mathrm{r}=0.86)$ between GLS values and the viability index of the myocardium examined using SPECT. ${ }^{13}$ Determination of cutoff value $\leq(-13 \%)$ to determine a moderate-large ischemic burden and $>\quad(-13 \%)$ to determine a small ischemic burden had $80 \%$ sensitivity and $75 \%$ specificity where AUC was $0.875(\mathrm{P}<0.001)$. This seems to be in line with some of the previous studies which averaged GLS values $<(-11 \%)$ to $(-13.7 \%)$ as this cutoff value in predicting myocardial viability. ${ }^{9,12,14}$

Comparison of the analysis of SPECT results between the two groups of GLS values based on the cutoff was compared. The result was founf a better left ventricular ejection fraction in the GLS value group $\leq(-13 \%)$ even though it was not significantly different from the GLS value group (-13\%). similar to previous studies, there was no significant relationship between GLS value and left ventricular ejection fraction. In that study a low correlation was found between the two parameters. And almost $90 \%$ addressed the group of patients with a reduction in ejection fraction $<50 \%$ but with normal GLS results $(<-18)$. And using the cutoff value $<(-13.5 \%)$ can get rid of patients with ejection fraction $<50 \%$ (Sensitivity $=86.07 \%$, Specificity $=82.97 \%, \mathrm{PPV}=55.0 \%, \mathrm{NPV}=$ $96.1 \%) .{ }^{15}$

The diagnostic test results in this study showed that GLS values $<(-13 \%)$ had $80 \%$ sensitivity, $75 \%$ specificity, PPV $67 \%$ and NPV $86 \%$ to determine a moderate-large ischemic burden in Investigating Myocardial Perfusion using SPECT. This shows that the value of GLS can be a simple marker that can predict ischemic burden, especially with the value of a small ischemic burden $(<10 \%)$ that can be used to determine whether it is beneficial for MVCAD patients if revascularization is performed.

From the results of this study it can be seen that the GLS value of echocardiography has a relationship with the ischemic burden value of the SPECT examination results $(\mathrm{P}<0.001)$. This result is in accordance with a study which states that GLS values are strongly influenced by the presence of residual ischemia in the myocardium in STEMI patients who are subject to SPECT examination to measure Infarct size, where residual ischemia is an independent factor in decreasing GLS values. ${ }^{10}$ Another study that examined the ability of GLS to predict the viability of myocardium compared to the results of LGE CMR examination found that GLS was a strong predictor for assessing non-viable myocardium. ${ }^{16}$ Some of these might explain why the value of GLS becomes an important marker that is often used to assess myocardial viability in patients with CAD.

\section{Limitation}

Limitation of this study is the small number of samples. Myocardial Perfusion Examination using SPECT performed on patients with a reduction in ejection fraction in this population so that the comparison of GLS values and ischemic burden does not include patients with good ejection fractions. Also this study only took the population in the Multivessel Coronary Artery Disease group so that patients with single or two vessel Coronary Artery Disease were not included in this study

\section{Conclusion}

There is a relationship between GLS values from echocardiography examination and the ischemic burden from the results of myocardial perfusion examination using SPECT in patients with Multivessel Coronary Artery Disease. GLS values $\leq(-13 \%)$ on echocardiography has a sensitivity (86\%) and specificity (75\%) that is good in determining moderate-to-large ischemic burden values $(>$ $10 \%)$. Moreover, using cut-off $(-13 \%)$ with $86 \%$ Negative Predictive Value, GLS values can estimate a small ischemic burden $(<10 \%)$.

\section{Acknowledgement}

Authors acknowledge these following persons: dr. Nizam Zikri Akbar, Sp.JP(K), dr. T. Bob Haykal, Sp.JP(K), Ns. Esti Suryani Napitupulu, dr. Bertha G Napitupulu, dr. Imy Ginting, dr. Rizki Anindita, dr. Mustajir Nur Arif.

\section{Funding Sources}

The authors declared no financial support for the research, authorship, and/or publication of this article

\section{Disclosures and Ethics}

The authors declared no potential conflicts of interest with respect to research, authorship, and /or publication of this article.

\section{References}

1. Shishehbor MH, Lauer MS, Singh IM, Chew DP, Karha J, Brener SJ, et al. 2007. In unstable angina or non-STsegment acute coronary syndrome, should patients with multivessel coronary artery disease undergo multivessel or culprit only stenting? J Am Coll Cardiol, 49:849-854.

2. Brown KA, Boucher CA, Okada RD, Guiney TE, Newell JB, Strauss HW, et al. 1983. Prognostic value of exercise thallium-201 imaging in patients presenting for evaluation of chest pain. J Am Coll Cardiol, 1:9941001.

3. Hachamovitch R, Berman DS, Shaw LJ, Kiat H, Cohen I, Cabico JA, et al. 1998. Incremental prognostic value of myocardial perfusion single photon emission computed tomography for the prediction of cardiac death: differential stratification for risk of cardiac death and myocardial infarction. Circulation, 97:535543. 
4. Wijns W, Kolh P, Danchin N, Mario CD, Falk V, Folliguet T, et al. 2010. Guidelines on myocardial revascularization. Eur Heart J, 31:2501-2555.

5. Hachamovitch R, Hayes SW, Friedman JD, Cohen I, Berman DS. 2003. Comparison of the short-term survival benefit associated with revascularization compared with medical therapy in patients with no prior coronary artery disease undergoing stress myocardial perfusion single photon emission computed tomography. Circulation, 107:2900-2907.

6. Hachamovitch R, Rozanski A, Shaw LJ, Stone GW, Thomson LEJ, Friedman JD, et al. 2011. Impact of ischaemia and scar on the therapeutic benefit derived from myocardial revascularization vs. medical therapy among patients undergoing stressrest myocardial perfusion scintigraphy. Eur Heart J, 32:1012-1024

7. Daly CA, Coelho-Filho OR, Kwong RY. 2011. Chronic myocardial ischemia and viability. In: Kramer CM, editor. Multimodality imaging in cardiovascular medicine. New York: Demos Medical Publishing.

8. Buckberg G, Hofman JI, Mahajan A, Saleh S, Coghlan C. 2008 Cardiac mechanics revisited: the relationship of cardiac architecture to ventricular function. Circulation, 118:2571-2587.

9. Amira MI, Wael S, Randa A, Fawzy S, Hussein K. 2015. Longitudinal strain in patients with STEMI using speckle tracking echocardiography. Correlation with peak infarction mass and ejection fraction. The Egyptian Journal of Critical Care Medicine, 3:45-53.

10. Aukelien C, Arthur J.H.A, Spyridon K, Hoogslag GE, Alexander R van Rosendael AR, van Zwetet EW, et al. 2017. Influence of myocardial ischemia extent on left ventricular global longitudinal strain in patients after ST-segment elevation myocardial infarction. Am J Cardiol, 119:1e6

11. Hanan R, Ekhlas H. 2017. Value of global longitudinal strain by two dimensional speckle tracking echocardiography in predicting coronary artery disease severity. Egypt Heart J, 69:95-101.

12. Sjoerd A, Victoria D, Matteo B, Antoni ML, Boersma E, Holman ER, et al. 2010. Viability assessment with global left ventricular longitudinal strain predicts recovery of left ventricular function after acute myocardial infarction. Circ Cardiovasc Imaging, 3:1523

13. Zhu W, Liu W, Tong Y, Xiao J. 2014. Threedimensional speckle tracking echocardiography for the evaluation of the infarct size and segmental transmural involvement in patients with acute myocardial infarction. Echocardiography, 31:58-66.

14. Chan J, Hanekom L, Wong C, Leano R, Cho GY, Marwick TH. 2006. Differentiation of subendocardial and transmural infarction using two-dimensional strain rate imaging to assess short-axis and long-axis myocardial function. J Am Coll Cardiol. 48:20262033.

15. Isabelle L, Brian Y, Haley B, Winchester S, Caldwell E, Lin $\mathrm{K}$, et al. 2018. The feasibility of global longitudinal strain in clinical practice and relationship with ejection fraction. J Am Coll Cardiol, 71(11 Supplement):A1716..

16. Migrino RQ, MD, Ahn KW, Brahmbhatt T, Harmann L, Jurva J, Pajewski NM. 2009. Usefulness of twodimensional strain echocardiography to predict segmental viability following acute myocardial infarction and optimization using bayesian logistic spatial modeling. Am J Cardiol, 104:1023-1029. 